\title{
PENGARUH KEDISIPLINAN DAN MOTIVASI TERHADAP KINERJA PEGAWAI PADA DINAS KESEHATAN KABUPATEN KUTAI BARAT DI SENDAWAR
}

\author{
Muchtar Hidayat \\ Sekolah Tinggi Ilmu Ekonomi Nasional (STIENAS) Samarinda \\ Jl. W. R. Supratman No. 10, Bugis, 75121, Indonesia \\ muchtarhidayat@gmail.com
}

\begin{abstract}
ABSTRAK
Tujuan penulisan ini adalah untuk mengetahui pengaruh yang signifikan variabel kedisiplinan dan motivasi secara bersama-sama terhadap kinerja pegawai pada Dinas Kesehatan Kabupaten Kutai Barat Di Sendawar. Dan juga untuk mengetahui kedisiplinan dan motivasi mana yang dominan pengaruhnya terhadap kinerja pegawai pada pada Dinas Kesehatan Kabupaten Kutai Barat Di Sendawar. Sedangkan kegunaan penulisannya adalah memberikan informasi mengenai kedisiplinan dan motivasi yang dapat mempengaruhi kinerja pegawai yang dapat membantu para pimpinan mengambil kebijakan untuk berusaha meningkatkan kedisiplinan dan motivasi agar terjadi peningkatan kinerja pegawai dan sekaligus kinerja Dinas Kesehatan Kabupaten Kutai Barat Di Sendawar itu sendiri.

Koefisien korelasi ( R) sebesar 0,9090 yang berarti bahwa variabel kedisiplinan dan motivasi secara bersama-sama mempunyai hubungan searah atau positif dengan kinerja pegawai pada Dinas Kesehatan Kabupaten Kutai Barat Di Sendawar. Nilai R Squared $\left(\mathrm{R}^{2}\right)$ sebesar 0,8260 atau 82,60\% yang berarti kinerja pegawai pada Dinas Kesehatan Kabupaten Kutai Barat Di Sendawar dapat ditentukan oleh variabel kedisiplinan dan motivasi. Dengan kata lain bahwa kontribusi kedisiplinan dan motivasi pegawai terhadap kinerja pegawai pada Dinas Kesehatan Kabupaten Kutai Barat Di Sendawar sebesar 82,60\%. Sedangkan sisanya $17,40 \%$ lainnya ditentukan oleh variabel lain diluar penelitian ini.

Sedangkan pengaruh masing-masing variabel yaitu variabel kedisiplinan $\left(\mathrm{X}_{1}\right)$ berpengaruh terhadap kinerja pegawai sebesar 56,20\%, sementara variabel motivasi $\left(\mathrm{X}_{2}\right)$ berpengaruh terhadap kinerja pegawai sebesar $65,00 \%$. Sehingga dapat dikatakan bahwa motivasi merupakan variabel yang pengaruhnya lebih besar terhadap kinerja pegawai pada Dinas Kesehatan Kabupaten Kutai Barat Di Sendawar. Uji hipotesis baik yang pertama

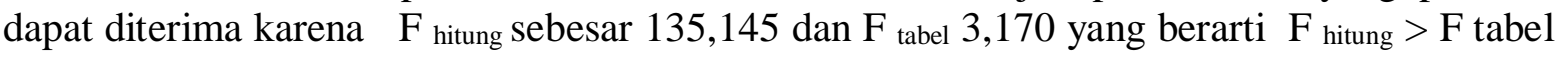
.Demikian juga dengan hipotesis kedua dapat diterima karena terbukti bahwa motivasi pengaruhnya lebih besar terhadap kinerja pegawai pada Dinas Kesehatan Kabupaten Kutai Barat Di Sendawar.
\end{abstract}

Keywords: Kedisplinan, Motivasi, Kinerja Pegawai.

PENDAHULUAN

Manusia merupakan sumber daya yang paling penting dalam suatu organisasi. Betapapun sempurnanya teknologi dalam suatu organisasi, tanpa manusia sangat sulit rasanya tujuan organisasi tercapai. Sumber daya manusia merupakan salah satu unsur masukan bersama unsur lain seperti: modal, bahan, mesin dan teknologi diubah melalui proses 
manajemen menjadi keluaran berupa barang atau jasa dalam usaha pencapaian tujuan organisasi.

Dalam suatu organisasi atau badan usaha senantiasa terdapat dua pola kepentingan, yaitu di satu pihak adalah peningkatan produktivitas kerja untuk pencapaian tujuan organisasi, dan di lain pihak untuk kepentingan kesejahteraan pegawai. Pimpinan organisasi harus dan perlu memberikan dorongan atau motivasi serta rangsangan (insentif) kepada pegawai, serta melakukan pengawasan secara terus-menerus terhadap seluruh pegawainya dalam peningkatan kinerja pegawai.

Kedisiplinan kerja pegawai merupakan syarat penting yang harus diperhatikan, apabila diharapkan tujuan nasional dapat dicapai secara efektif atau berhasil guna. Dengan adanya tingkat disiplin kerja yang dimiliki para pegawai, berarti para pegawai akan melaksanakan tugasnya sesuai dengan apa yang telah ditentukan sebelumnya. Pegawai yang disiplin tidak akan melalaikan tugasnya serta kewajibannya ataupun menyalah gunakan kewenangan yang dimilikinya.

Kedisiplinan kerja yang diharapkan dari para pegawai adalah berupa disiplin kerja yang positif, yaitu suatu disiplin yang didasarkan kepada tanggung jawab dan kesadaran dari pegawai yang bersangkutan. Dengan disiplin yang diharapkan, dengan penuh pengabdian, rajin, jujur, hemat serta bersemangat tinggi sehingga dapat mencapai hasil dari pekerjaannya. Disiplin yang semacam itulah yang harus dimiliki setiap pegawai.

Tenaga kerja (pegawai) merupakan faktor produksi yang perlu diperhatikan agar kelangsungan hidup suatu organisasi atau instansi tetap terjaga. Perhatian dilakukan harus dapat ditujukan pada kedisiplinan pegawai yang melakukan segala aktivitas organisasi. Hal ini memang penting karena peningkatan sumber daya manusia dapat dilihat dari kedisiplinan pegawai itu sendiri. 
Motivasi merupakan menyeluruh terhadap para kegiatan yang dapat menyebabkan, menyalurkan, mendukung dan memelihara perilaku manusia, supayah mau bekerja giat dan antusias mencapai hasil yang optimal. Motivasi juga selalu menjadi perhatian utama dari para pimpinan, karena motivasi berhubungan erat dengan keberhasilan seseorang, organisasi atau masyarakat malam mencapai tujuan-tujuannya. Hal ini penting sebab dalam performasi kerja akan berkaitan dengan dua faktor utama yaitu; pertama, kesediaan atau motivasi dari pegawai untuk berkerja dan dapat menimbulkan usaha pegawai, dan kedua kemampuan pegawai untuk melaksanakannya. Jadi motivasi berkaitan dengan tingkat usaha yang dilakukan oleh seseorang (pegawai) dalam mengejar suatu tujuan yang telah ditetapkan.

Dalam meningkatkan kinerja pegawai maka Dinas Kesehatan Kabupaten Kutai Barat di Sendawar mengambil satu alternative atau langkah dengan menerapkan suatu sistem kedisiplinan secara pegawai yang bertugas, dengan tidak melupakan hak-hak pegawai. Sehubungan uraian latar belakang tersebut, maka penelitian ini akan dilakukan dengan judul "Pengaruh Kedisiplinan dan Motivasi Terhadap Kinerja Pegawai Pada Dinas Kesehatan Kabupaten Kutai Barat di Sendawar".

\section{TINJAUAN PUSTAKA}

\section{Manajemen Kinerja}

Manajemen kinerja adalah suatu proses yang dirancang untuk meningkatkan kinerja organisasi, kelompok dan individu yang digerakkan oleh para manajer. Pada dasarnya manajemen kinerja adalah suatu proses yang dilaksanakan secara sinergi antara manajer, individu dan kelompok terhadap suatu pekerjaan di dalam organisasi. Proses ini lebih didasarkan pada prinsip manajemen sasaran daripada manajemen berdasarka n perintah, meskipul hal tersebut juga mencakup kebutuhan untuk menekankan pada harapan kinerja yang tinggi melalui kontrak semacam itu. 
Menurut Armstrong dikutip oleh (Wibowo, 2008 : 299), Manajemen Kinerja sebagai sarana untuk mendapatkan hasil yang lebih baik dari organisasi, tim, dan individu dengan cara memahami dan mengolah kinerja dalam suatu kerangka tujuan, standar, dan persyaratanpersyaratan atribut yang disepakati. Bacal dikutip oleh (Wibowo, 2008 : 299) memandang manajemen kinerja sebagai proses komunikasi yang berkesinambungan dan dilakukan dalam kemitraan antara seorang pegawai dan atasan langsungnya.

Armstrong dan Baron dikutip oleh (Wibowo, 2008 : 299) sebelumnya berpandangan bahwa Manajemen Kinerja merupakan pendekatan strategis dan terpadu untuk menyampaikan sukses berkelanjutan pada organisasi dengan memperbaiki kinerja karyawan yang bekerja di dalamnya dan dengan mengembangkan kapabilitas tim dan kontributor individu. Selanjutnya Noe, dkk yang dikutip oleh Surya Dharma (2005:19) menyebutkan tiga tujuan manajemen kinerja yaitu:

a. Tujuan Stratejik

Manajemen kinerja harus mengaitkan kegiatan pegawai dengan organisasi. Pelaksanaan strategi tersebut perlu mendefinisikan hasil yang akan dicapai, perilaku, karakteristik pegawai yang dibutuhkan untuk melaksanakan strategi, mengembangkan pengukuran dan sistem umpan balik terhadap kinerja pegawai;

b. Tujuan Administratif Kebanyakan organisasi menggunakan informasi manajemen kinerja khususnya evaluasi kinerja untuk kepentingan keputusan administratif, seperti penggajian, promosi, pemberhentian pegawai dan lain-lain.

c. Tujuan Pengembangan

Manajemen kinerja bertujuan mengembangkan kapasitas pegawai yang 


berhasil di bidang
kerjanya. Pegawai yang
tidak berkinerja baik perlu
mendapat pemberdayaan
melalui training,
penempatan yang lebih
cocok dan sebagainya.
Pihak manajemen perlu
memahami apa saja yang
menyebabkan pegawai
tidak berkinerja baik,
apabila faktor skill,
motivasi, dan lain-lain
sehingga dapat diambil
langkah-langkah
perbaikan kinerjanya.

Menurut Surya Dharma (2005: 25), Manajemen Kinerja adalah suatu cara untuk mendapatkan hasil yang lebih baik bagi organisasi, kelompok dan individu dengan memahami da mengelola kinerja sesuai dengan target yang telah direncanakan, standar dan persyaratan kompetensi yang telah ditentukan. Dengan demikian manajemen kierja adalah sebuah proses untuk menetapkan apa yang harus dicapai, dan pendekatannya untuk mengelola dan mengembangkan manusia melalui suatu cara yang dapat meningkatkan kemungkinan bahwa sarana akan dapat dicapai dalam suatu jangka waktu tertentu baik pindek maupun panjang.

\section{Kinerja}

Istilah kinerja berasal dari kata job performance atau actual performance (prestasi kerja atau prestasi sesungguhnya yang dicapai oleh seseorang). Hal ini seperti yang tertera dalam keputusan Menteri Keuangan Republik Indonesia Nomor : 740 / KMK.00 /1989. Yang dikutip (Sedarmayanti, 2001: 46). Kinerja adalah prestasi yang dicapai oleh perusahaan atau lembaga atau organisasi dalam satu periode tertentu yang mencerminkan tingkat kesehatan lembaga atau perusahaan atau organisasi. Adapun pengertian lain yang dikemukakan oleh para praktisi dimana hanya memberikan penjelasan hasil-hasil kinerja tersebut. Jadi kinerja merupakan suatu penilaian kerja yang umumnya mencakup aspek manajemen dan keuntungan yang diperoleh dari pada pelaksanaan pekerjaan sehingga dapat memperoleh hasil yang diharapkan. 
Menurut Anwar Prabu Mangkunegara (2004: 67) bahwa Kinerja adalah hasil kerja secara kualitas dan kuantitas yang dicapai oleh seseorang pegawai dalam melaksanakan tugasnya sesuai dengan tanggung jawab yang diberikan kepadanya. Menurut L.A.N., yang dikutip (Sedarmayanti, 2001 : 50) pengertian kinerja sebagai berikut : "Performance diterjemakan menjadi kinerja, juga berarti prestasi kerja, pelaksanaan kerja, pencapaian kerja atau hasil kerja/unjuk kerja/penampilan kerja."

Menurut Lawler dan Porter yang dikutip oleh (Moh. As'ad, 2000: 47-48) sebagai berikut: “Job performance adalah "Successful role achievement" yang diperoleh seseorang dari perbuatanperbuatannya."Dari pengertian di atas jelaslah bahwa yang dimaksud dengan job performance adalah hasil yang dicapai oleh seseorang menurut ukuran yang berlaku untuk pekerjaan bersangkutan. Sedangkan David Fitt dikutip Basir Barthos (2003 : 131) mengemukakan Kinerja adalah pernyataan sejauh mana seseorang telah menanamkan bagiannya dalam melaksanakan strategi organisasi, baik dalam mencapai sasaran-sasaran khusus yang berhubungan dengan peranan seseorang, dan atau dengan memperhitungkan kompetensikompetensi yang dinyatakan relevan bagi organisasi, apakah dalam satu peran tertentu atau secara lebih umum.

\section{Penilaian Kinerja}

Penilaian kinerja merupakan suatu alat yang berfaedah tidak hanya untuk mengevaluasi kerja para karyawan, tetapi juga untuk mengembangkan dan memotivasi kalangan karyawan. Pada intinya penilaian kinerja dapat dianggap sebagai alat untuk memverifikasi bahwa individu memenuhi standar kinerja yang telah ditetapkan. Penilaian kinerja dapat pula menjadi cara untuk membantu para karyawan mengelola kinerja mereka.

Menurut Hery Simamora (2004 : 338), Penilaian Kinerja merupakan salah satu aktivitas dasar departemen sumber daya manusia, kadangkadang disebut juga dengan telaah kinerja, penilaian karyawan, evaluasi kinerja, evaluasi karyawan, atau penentuan peringkat personalia. Dilihat secara keseluruhan penilaian kinerja merupakan proses yang 
berbeda dari evaluasi. Penilaian kinerja berkenaan dengan seberapa baik seseorang melakukan pekerjaan yang ditugaskan atau diberikan. Sedangkan evaluasi pekerjaan menentukan seberapa tinggi harga sebuah pekerjaan bagi organisasi, sehingga dapat diperkirakan berapa gaji sepatutnya diterima seorang pekerja.

\section{Faktor Yang Mempengaruhi}

\section{Kinerja}

Faktor merupakan elemenelemen yang berhubungan dengan pencapaian suatu hasil dari upaya kegiatan yang dilakukan oleh setiap individu maupu sekelompok orang. Dengan faktor-faktor tersebut dapat mendukung dan meningkatkan kinerja setiap orang sehingga tercapainya suatu hasil yang diinginkan oleh setiap organisasi. Dengan demikian kinerja merupakan hasil yang diperoleh baik itu secara individu maupun kelompok.

A.A. Anwar Prabu Mangkunegara (2004: 67) mengemukakan pendapatnya bahwa: "Faktor yang mempengaruhi pencapaian kinerja adalah faktor kemampuan (ability) dan faktor motivasi (motivation)".

Jadi dapat disimpulkan bahwa faktor yang mempengaruhi pencapaian kinerja adalah faktor kemampuan dan motivasi :

a) Faktor Kemampuan

Secara psikologis, kemampuan karyawan terdiri dari kemampuan potensi (IQ) dan kemampuan reality, artinya karyawan yang memiliki IQ di atas rata-rata (IQ 110 - 120) dengan pendidikan yang memadai untuk jabatannya dan terampil dalam mengerjakan kegiatan sehari-hari, maka ia akan lebih mudah mencapai kinerja yang diharapkan.

b) Faktor Motivasi

Motivasi terbentuk dari sikap seseorang karyawan dalam menghadapi situasi kerja. Motivasi merupakan kondisi yang menggerakkan diri karyawan yang terarah untuk mencapai tujuan organisasi (tujuan kerja).

Kinerja mempunyai hubungan yang erat dengan masalah produktivitas karena merupakan indikator dalam menentukan bagaimana usaha untuk mencapai tingkat produktivitas yang tinggi dalam suatu organisasi. Sehubungan 
dengan hal tersebut maka upaya untuk mengadakan penilaian terhadap kinerja disuatu organisasi merupakan hal penting. Berbicara tentang kinerja personil (pegawai), berarti mengadakan penilaian terhadap pekerjaan seseorang sehingga perlu ditetapkan stansar kinerja atau standard performance. Hal ini untuk dapat mengetahui kemampuan para pegawai (karyawan) tersebut dan pada akhirnya akan meningkatkan penghasilan yang diperolehnya sesuai dengan hasil kerja yang dicapainya.

Menurut Ambar Teguh Sulistiyani \& Rosidah (2003 : 228), ada enam kriteria yang mempengaruhi kinerja pegawai, antara lain:

a. Kualitas, menyangkut kesesuaian hasil dengan yang diingini;

b. Kuantitas, jumlah yang dihasilkan baik dalam nilai uang, jumlah unit atau jumlah lingkaran aktivitas;

c. Ketepatan waktu;

d. Efektivitas biaya, menyangkut penggunaan resorsis organisasi secara maksimal; e. Kebutuhan supervisi, menyangkut perlunya bantuan atau intervensi supervisi dalam pelaksanaan pegawai;

f. Dampak interpersonal, menyakut peningkatan harga diri, hubungan baik, kerjasama diantara teman kerja maupun bawahan.

\section{Kedisiplinan}

$$
\text { Kata }
$$

Disiplin

(Terminologis) berasal dari kata latin yaitu Disciplina yang artinya pengajaran atau latihan. Banyak orang memberikan pengertian kedisiplinan adalah bilamana karyawan selalu dan datang serta pulang tepat pada waktunya. Sebenarnya gambaran itu mungkin adalah salah satu kedisiplinan yang dituntut oleh perusahaan tersebut.

Definisi Disiplin Kerja menurut Muchdarsyah Sinungan (2001 : 145) adalah mengacu pada pola tingkah laku dengan ciri-ciri adanya hasrat yang kuat untuk melaksanakan sepenuhnya apa yang sudah menjadi norma atau aturan-aturan yang berlaku,adanya perilaku yang dilakukan dan adanya ketaatan. 
Disiplin adalah sebagai sikap mental yang tercermin dalam perbuatan,atau tingkah laku perorangan, kelompok atau masyarakat berupa ketaatan terhadap peraturan-peraturan atau ketentuan yang diterapkan. Disiplin dapat dikembangkan melalui suatu latihan antara lain bekerja menghargai waktu,tenaga dan biaya. Menurut Ig, Suroso (2002 : 2), Disiplin adalah peraturan yang dilakukan dengan tegas dan ketat serta menghendaki dilaksanakannya segala peraturan yang dilakukan dengan teliti dan murni bahkan hal-hal yang terkecilpun tak boleh disimpan.

Disiplin yang dimaksud adalah ketaatan yang berasal dari kesadaran sendiri bukan karena paksaan orang lain, apabila terjadi pelanggaran terhadap disiplin maka terdapat sangsi atau hukuman. Menurut Alex Nitisemito (2002 : 91), Disiplin Kerja adalah suatu sebab mengapa dari pribadi-pribadi atau kelompok-kelompok dengan senantiasa mau melaksanakan perintah-perintah atasannya

dengan cara sebaik-baiknya dan seefisien. Manusia yang sukses adalah manusia yang mampu mengatur,mengendalikan diri yang menyangkut pengaturan cara hidup dan cara kerja. Maka erat hubungannya antara pribadi sukses dan pribadi disiplin.

Definisi Disiplin Kerja menurut Sondang P.Siagian (2005: 305) merupakan tindakan manajemen untuk mendorong para anggota organisasi tuntutan berbagai ketentuan. Dengan perkataan lain,pendisiplinan tenaga kerja adalah suatu bentuk pelatihan yang berusaha memperbaiki dan membentuk sikap dan perilaku karyawan sehingga karyawan itu secara sukarela berusaha bekerja secara kooperatif dengan para karyawan lain serta meningkatkan prestasi kerjanya.

$\begin{array}{lr}\text { Kedisiplinan } & \text { tersebut } \\ \text { merupakan fungsi } & \text { operatif } \\ \text { Manajemen Sumber } & \text { Daya } \\ \text { Manusia yang terpenting, karena } \\ \text { semakin baik disiplin karyawan, } \\ \text { semakin tinggi prestasi kerja } \\ \text { yang dapat dicapainnya. Tanpa } \\ \text { disiplin pegawai yang baik, sulit }\end{array}$


bagi organisasi instansi mencapai hasil yang optimal. Oleh karena itu kedisiplinan harus ditegakkan dalam suatu organisasi perusahaan, karena tanpa dukungan disiplin pegawai yang baik, maka sulit instansi untuk mewujudkan tujuannya. Jadi, kedisiplinan merupakan kunci keberhasilan suatu instansi dalam mencapai tujuan.

\section{Motivasi}

Kusnadi dkk (2002 : 330) memberikan pengertian

Motivasi sebagai semua upaya untuk memunculkan dari dalam semangat orang lain (bawahan) agar mau bekerja keras guna mencapai tujuan organisasi melalui pemberian atau penyediaan pemuasan kebutuhan mereka. Menurut Malayu S.P. Hasibuan (2005 : 156), Motivasi adalah hal yang menyebabkan, menyalurkan dan mendukung perilaku manusia supaya mau bekerja giat dan antusias untuk mencapai hasil yang optimal. Hal ini senada yang diungkapkan oleh Sondang P. Siagian (2004:138) menyatakan Motivasi sebagai daya pendorong yang mengakibatkan seseorang atau organisasi mau dan rela untuk mengerahkan kemampuan - dalam bentuk keahlian atau ketrampilantenaga dan waktunya untuk menyelenggarakan berbagai kegiatan yang menjadi tanggung jawabnya dan menunaikan kewajibannya, dalam rangka pencapaian tujuan dan berbagai sasaran organisasi yang telah ditentukan sebelumnya.

Abraham Maslow yang dikutip oleh (T. Hani Handoko,2004:256) menyatakan manusia akan didorong untuk memenuhi kebutuhan paling kuat sesuai waktu, keadaan dan pengalaman yang bersangkutan mengikuti suatu hirarki. Dalam tingkatan ini kebutuhan pertama yang harus dipenuhi terlebih dahulu adalah kebutuhan fisiologis seperti istirahat dan sebagainya. Setelah kebutuhan pertama dipuaskan, kebutuhan yang lebih tinggi berikut akan menjadi kebutuhan utama, yaitu kebutuhan akan keamanan dan rasa aman. Kebutuhan ketiga akan muncul setelah kebutuhan 
kedua terpuaskan. Proses ini berjalan terus sampai terpenuhinya kebutuhan aktualisasi diri.

Hal ini senada yang diungkapkan oleh John P. Campbell, et.al dikutip (Henry Simamora, 2004 memberikan pengertian Motivasi mencakup di dalamnya arah dan tujuan tingkah laku, kekuatan respon dan kegigihan tingkah laku. Disamping itu, istilah itu mencakup sejumlah konsep seperti dorongan (drive), kebutuhan (needs), rangsangan (incentive), ganjaran (reward), penguatan (reinforcement), ketepatan tujuan (goal setting), harapan (expentancy), dan sebagainya.

Berbicara mengenai kebutuhan manusia, seorang psikolog terkenal A.H Maslow mengemukakan bahwa manusia memiliki kategori kebutuhan pokok, yang dikutip oleh Sondang P. Siagian (2005: 146 $-153)$.

\section{Faktor Motivasi}

Pekerjaan sendiri merupakan suatu pertimbangan yang sangat penting dalam motivasi, pekerjaan telah dipandang sebagai suatu pemberi kesempatan untuk ikut serta mengembangkan dan membntu penduduknya. Motivasi seorang pekerja untuk bekerja biasanya merupakan hal yang rumit, karena motivasi itu menitikberatkan pada faktorfaktor individual dan faktorfaktor organisasional. Faustino Cardoso Gomes (2003: 187) mengemukakan faktor motivasi terdiri dari 2 (dua) faktor sebagai berikut. Faktor-faktor yang sifatnya indifidual yang meliputi; kebutuhan-kebutuhan (needs), tujuan-tujuan (gools), sikap (attihudes), dan kemampuankemampuan (abilities). Faktorfaktor yang berasal dari organisasi meliputi; pembayaran atau gaji (pay), keamanan pekerjaan (job security), sesama pekerja (co-workers), pengawasan (supervision), pujian (praise), dan pekerjaan itu sendiri (job itself).

Dari uaraian faktor motivasi tersebut di atas dapat diarahkan untuk memberikan 
suatu rangsangan kepada bawahan agar dapat melakukan tugas yang diberikannya dengan baik. Alat perangsang yang diberikan kepada bawahan guna dapat meningkatkan prestasi kerja karyawan. H. Malayu S.P. Hasibuan

mengemukakan alat-alat motivasi atau daya perangsan yaitu sebagai berikut :

1. Mateial incentive adalah motivasi yang bersifat materiil sebagai imbalan prestasi yang diberikan oleh karyawan. Yang termasuk material incentive adalah yang berbentuk uang dan barang-barang.

2. Nonmaterial incentive adalah motivasi (daya perangsang) yang tidak berbentuk materi. Yang termasuk nonmaterial adalah penempatan yang tepat, pekerjaan yang terjamin, piagam penghargaan, bintang jasa, perlakuan yang wajar, dan sejenisnya. (Hasibuan, 2005 : 150)

\section{Kerangka Konsep}

Untuk memudahkan pemahaman tentang kedisiplinan dan motivasi sebagai variable independent (bebas) terhadap kinerja pegawai sebagai variable dependent (terikat), maka dapat digambarkan dalam kerangka konsep sebagai berikut:

Variabel independent (X)

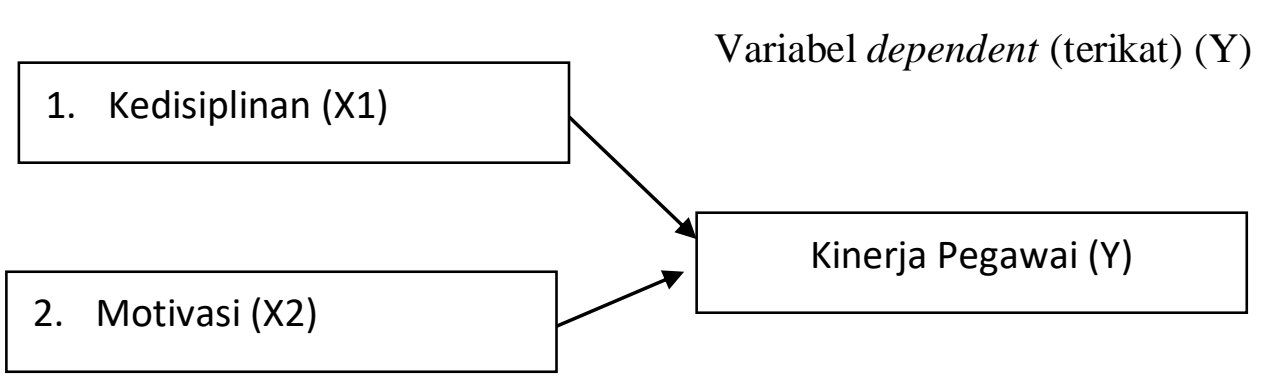

\section{Gambar 1 Kerangka Konsep}

Dalam penelitian ini penulis memilih Lokasi penelitian pada Dinas Kesehatan Kabupaten Kutai Barat Di Sendawar. Penelitian ini dibatasi hanya pada masalah kedisiplinan dan motivasi pegawai pada Dinas Kesehatan Kabupaten Kutai Barat Di Sendawar. Untuk mengetahui seberapa besar 
kedisiplinan dan motivasi yang mempengaruhi kinerja pegawai pada Dinas Kesehatan Kabupaten Kutai Barat Di Sendawar, maka yang menjadi variabel dependen adalah kinerja pegawai (Y) sedangkan variabel independent adalah yang meliputi kedisiplinan (X1) dan motivasi (X2). Persamaan dituliskan sebagai berikut :

$\mathrm{Y}=\mathrm{a}+\mathrm{b}_{1} \mathrm{X}_{1}+\mathrm{b}_{2} \mathrm{X}_{2}+\mathrm{e}$

Dimana $\mathrm{Y}=$ Kinerja Pegawai, $\mathrm{a}=$ Konstanta, $X_{1}=$ Kedisiplinan, $X_{2}=$
Motivasi, $\mathrm{b}_{1}, \mathrm{~b}_{2}=$ Koefisien Regresi, e = Kesalahan Pengganggu .

\section{HASIL DAN PEMBAHASAN}

Untuk memperoleh jawaban atas permasalahan yang dihadapi, maka data-data hasil kuisioner perlu dianalisis dengan menggunakan melalui perhitungan tersebut yaitu analisis regresi berganda dengan menggunakan SPSS versi 17 dengan hasil sebagai berikut :

Tabel 1 : Descriptive Statistics

\begin{tabular}{llll} 
Keterangan & Mean & Std Deviation & N \\
\hline Kinerja Pegawai & 3,3625 & 0,35780 & 60 \\
Kedisiplinan & 3,2792 & 0,39620 & 60 \\
Motivasi & 3,2292 & 0,43979 & 60
\end{tabular}

Sumber: Hasil perhitungan SPSS versi 17

Tabel 2 : Model Summary

\begin{tabular}{llllll} 
Model & $\mathrm{R}$ & $\mathrm{R}$ Square & $\begin{array}{l}\text { Adjuted } \\
\text { Square }\end{array}$ & $\mathrm{R}$ & $\begin{array}{l}\text { Std.Error of the } \\
\text { Estimate }\end{array}$ \\
\hline 1 & 0,909 & 0,826 & 0,820 & 0,15191
\end{tabular}

Sumber : Hasil perhitungan SPSS versi 17

Tabel 3: ANOVA

\begin{tabular}{cllllll} 
Model & & $\begin{array}{l}\text { Sum of } \\
\text { Square }\end{array}$ & df & $\begin{array}{l}\text { Mean } \\
\text { Square }\end{array}$ & F & Sig \\
\hline 1 & Reression & 6,238 & 2 & 3,119 & 135,145 & 0,00000 \\
& Residual & 1,315 & 57 & 0,032 & & \\
& Total & 7,553 & 59 & & &
\end{tabular}

Sumber: Hasil perhitungan SPSS versi 17

Tabel 4: T hitung

\begin{tabular}{llllll}
\multirow{2}{*}{ Model } & \multicolumn{2}{l}{$\begin{array}{l}\text { Unstandardized } \\
\text { Coefficients }\end{array}$} & \multicolumn{2}{l}{$\begin{array}{l}\text { Standardized } \\
\text { Coefficients }\end{array}$} & $\mathrm{t}$ \\
\cline { 2 - 4 } & $\mathrm{B}$ & $\begin{array}{l}\text { Std } \\
\text { Error }\end{array}$ & Beta & Hitung & Sig \\
\hline ( Constant) & 0,670 & 0,168 & & 3,981 & 0,000 \\
Kedisiplinan & 0,388 & 0,076 & 0,430 & 5,130 & 0,000 \\
Motivasi & 0,440 & 0,068 & 0,541 & 6,453 & 0,000
\end{tabular}

Sumber: Hasil perhitungan SPSS versi 17 
Tabel 5: Coefficients Partial

Model

Correlations

$$
\text { Zero-Zero }
$$

Partial

Part

(Constant)

Kedisiplinan

Motivasi

0,836

0,562

0,284

0,863

0,650

0,357

Sumber: Hasil perhitungan SPSS versi 17

Tabel 6: Rekapitulasi Hasil Perhitungan Regresi Dan Korelasi

\begin{tabular}{|c|c|c|c|c|c|}
\hline Variabel & $\begin{array}{l}\text { Regression } \\
\text { Coefficient }\end{array}$ & Std Error & $\begin{array}{l}\mathrm{T} \\
(\mathrm{DF}=45)\end{array}$ & Prob. & $\begin{array}{l}\text { Partial } \\
\mathrm{r}^{2}\end{array}$ \\
\hline$X_{1}$ & 0,388 & 0,076 & 5,130 & 0,000 & 0,562 \\
\hline $\mathrm{X}_{2}$ & 0,440 & 0,068 & 6,453 & 0,000 & 0,650 \\
\hline Constanta & 0,718 & & & & \\
\hline R Squared & $=0,826$ & & F Ratio & \multirow{2}{*}{\multicolumn{2}{|c|}{$\begin{array}{l}=135,145 \\
=0,000\end{array}$}} \\
\hline Multiple R & $=0,909$ & & Prob & & \\
\hline
\end{tabular}

Hasil perhitungan dengan menggunakan SPSS versi 17 diperoleh persamaan regresi berganda $\mathrm{Y}=0,670+0,388 \mathrm{X}_{1}+$ $0,440 \mathrm{X}_{2}$. Yang berarti bila $\mathrm{X}_{1}$ (Kedisiplinan) berubah dengan satu satuan maka $\mathrm{Y}($ Kinerja Pegawai) akan bertambah sebesar 0,388 satuan dengan asumsi $\mathbf{X}_{2}$. tetap atau konstan. Bila $\mathrm{X}_{2}$ (Motivasi) berubah dengan satu satuan maka Y (Kinerja Pegawai) akan bertambah sebesar 0,440 satuan dengan asumsi $X_{1}$ tetap atau konstan. Untuk melihat pengaruh secara bersama-sama variabel kedisiplinan dan motivasi terhadap kinerja pegawai Pada Dinas Kesehatan Kabupaten Kutai Barat Di Sendawar, ditunjukkan $\mathrm{R}$ Squared $\left(\mathrm{R}^{2}\right)$ dengan nilai sebesar
0,826 , yang berarti bahwa $82,60 \%$ faktor kedisiplinan dan motivasi mempengaruhi kinerja pegawai pada Dinas Kesehatan, sisanya 17,40 $\%$ dipengaruhi oleh variabel lain yang tidak termasuk bagian dari variabel terpilih dalam penelitian ini..

Hasil perhitungan lain diperoleh koefisien korelasi ( $\mathrm{R}$ ) sebesar 0,909 atau 90,90\%. Hal ini berarti bahwa secara bersama-sama variabel kedisiplinan (X1) dan motivasi (X2) mempunyai hubungan yang erat dengan kinerja pegawai Dinas Kesehatan Kabupaten Kutai Barat. Sedangkan pengaruh masing-masing variabel $\mathrm{X}$ terhadap variabel Y adalah sebagai berikut: Hubungan antara kedisiplinan $\left(\mathrm{X}_{1}\right)$ terhadap kinerja pegawai (Y) sebesar 0,562 atau 56,20 
$\%$ dengan signifikansi 0,000 yang berarti $\mathrm{X}_{1}$ mempengaruhi $\mathrm{Y}$ dengan asumsi $\mathrm{X}_{2}$ tetap. Hubungan antara motivasi $\mathrm{X}_{2}$ terhadap kinerja pegawai Y sebesar 0,650 atau $65,50 \%$ dengan signifikansi 0,000 yang berarti $\mathrm{X}_{2}$ mempengaruhi $\mathrm{Y}$ dengan asumsi $\mathrm{X}_{1}$ tetap.

Dengan uji $F$ pada tingkat kepercayaan $95 \%$ dan dan alfa $(\alpha)$ 0,05 diperoleh besaran $\mathrm{F}_{\text {hitung }}$ berdasarkan tabel analysis of Variance (ANOVA) program SPSS ver. 17 seperti tabel 7 atau tabel terlampir sebesar 135,145 dengan probabilitas sig. 0,000, sedangkan F tabel sebesar 3,170 dengan alfa (a) 0,05. Hal ini mengindikasikan bahwa variabel kedisiplinan dan motivasi secara bersama-sama atau secara simultan berpengaruh signifikan terhadap kinerja pegawai Dinas.

Dengan memperhatikan hasil analisis dengan menggunakan SPSS versi 17 diperoleh persamaan regresi linier berganda sebagai berikut $\mathrm{Y}=0,670+0,388$ $\mathrm{X}_{1}+0,440 \quad \mathrm{X}_{2}$, yang berarti bahwa variabel kedisiplinan dan motivasi secara bersama-sama mempunayi hubungan dengan kinerja pegawai Dinas Kesehatan
Kabupaten Kutai Barat. $\mathrm{a}=0,670$; adalah bilangan konstanta, artinya tidak ada yang menunjukkan ratarata pengaruh berbagai variabel yang mempengaruhi variabel terikat (Y) atau sebagai perkiraan rata-rata nilai $\mathrm{Y}$, bila semua variabel bebas konstan $(\mathrm{X} 1=\mathrm{X} 2$ $=0)$. Hal ini menunjukkan bahwa jika kedisiplinan dan motivasi tidak di nilai, maka kinerja pegawai akan bernilai konstanta atau tetap. $\mathrm{b} 1=0,388$ adalah bilangan koefisien regresi untuk variabel kedisiplinan $\left(\mathrm{X}_{1}\right)$ Artinya apabila kedisiplinan meningkat atau berkurang sebesar satu satuan, dan variabel lain konstan, maka kinerja pegawai akan meningkat atau bertambah sebesar 0,388 satuan. $\mathrm{b} 2=0,440$; adalah bilangan koefisien regresi untuk variabel motivasi $\left(\mathrm{X}_{2}\right)$. Artinya apabila penilaian motivasi bertambah sebesar satu satuan dan variabel lain konstan, maka kinerja pegawai meningkat atau bertambah sebesar 0,440 satuan.

Koefisien korelasi ( $\mathrm{R})$ sebesar 0,9090 yang berarti bahwa variabel kedisiplinan dan motivasi secara bersama-sama mempunyai hubungan searah atau positif 
dengan kinerja pegawai Dinas Kesehatan Kabupaten Kutai Barat. Nilai R Squared $\left(\mathrm{R}^{2}\right)$ sebesar 0,8260 atau $82,60 \%$ yang berarti kinerja pegawai pada Dinas Kesehatan Kabupaten Kutai Barat dapat ditentukan oleh variabel kedisiplinan dan motivasi. Dengan kata lain bahwa kontribusi kedisiplinan dan motivasi pegawai terhadap kinerja pegawai pada Dinas Kesehatan Kabupaten Kutai Barat sebesar $81,50 \%$. Sedangkan sisanya $\quad 17,40 \quad \% \quad$ lainnya ditentukan oleh variabel lain diluar penelitian ini. Sementara keeratan hubungan dari masingmasing variabel adalah sebagai berikut:

1. Variabel kedisiplinan $\left(X_{1}\right)$ koefisien korelasi parsial (r) sebesar 0,836 yang artinya mempunyai arah hubungan positif dengan kinerja pegawai pada Dinas Kesehatan Kabupaten Kutai Barat.

2. Variabel motivasi $\left(X_{2}\right)$ koefisien korelasi parsial (r) sebesar 0,863 yang artinya mempunyai arah hubungan positif dengan kinerja pegawai pada Dinas Kesehatan Kabupaten Kutai Barat.
Sedangkan pengaruh masing-masing variabel yaitu variabel kedisiplinan $\left(\mathrm{X}_{1}\right)$ berpengaruh terhadap kinerja pegawai sebesar 56,20 \%, sementara variabel motivasi $\left(\mathrm{X}_{2}\right)$ berpengaruh terhadap kinerja pegawai sebesar $65,00 \%$. Sehingga dapat dikatakan bahwa motivasi merupakan variabel yang pengaruhnya lebih besar terhadap kinerja pegawai pada Dinas Kesehatan Kabupaten Kutai Barat. Hal ini dikarenakan semakin motivasi pegawai maka semakin besar pula tingkat kinerja yang dicapai pada Dinas Kesehatan Kabupaten Kutai Barat.

\section{KESIMPULAN}

Berdasarkan analisis dam pembahasan peneliti dapat mengambil simpulan akhir sebagai berikut :

1. Bahwa dari dua variabel independen dan satu variabel dependen yang di teliti secara parsial di mana variabel kedisiplinan dan motivasi berpengaruh signifikan terhadap kinerja pegawai pada Dinas Kesehatan Kabupaten Kutai Barat Di Sendawar. 
2. Secara serentak seluruh variabel independen seperti, variabel kedisiplinan dan motivasi berpengaruh secara serentak dan signifikan terhadap kinerja pegawai pada Dinas Kesehatan Kabupaten Kutai Barat Di Sendawar. Variabel independen tersebut cocok digunakan untuk meramal variabel dependen.

3. Hipotesis yang diajukan baik hipótesis pertama maupun kedua dapat diterima dengan asumsi bahwa hipótesis pertama menyatakan variabel kedisiplinan dan motivasi secara serentak berpengaruh terhadap kinerja pegawai pada Dinas Kesehatan Kabupaten Kutai Barat Di Sendawar. Sedangkan hipótesis kedua menyatakan bahwa variabel motivasi lebih dominan berpengaruh terhadap kinerja pegawai pada Dinas Kesehatan Kabupaten Kutai Barat Di Sendawar.

\section{SARAN}

Berdasarkan hasil analisis dan beberapa simpulan tersebut, dapat disusun beberapa saran sebagai berikut:
1. Diharapkan kepala Dinas Kesehatan Kabupaten Kutai Barat Di Sendawar, tetap memberikan perhatian yang optimal terhadap faktor kedisiplinan dan motivasi karena kedua faktor tersebut sangat berpengaruh terhadap kinerja pegawai tersebut.

2. Meskipun faktor motivasi kerja berpengaruh dominan terhadap kinerja pegawai Dinas Kesehatan Kabupaten Kutai Barat Di Sendawar, namun kiranya kedisiplinan yang mempunyai pengaruh terkecil diupayakan ditingkatkan. Hal ini penting dilakukan agar dapat mendorong kinerja pegawai menjadi lebih baik.

3. Bagi peneliti berikutnya, terutama yang ingin melakukan penelitian lanjutan sejenis secara komprehensif, kiranya dapat menambah variabel-variabel lain yang relevan kea rah pengembangan teori kinerja dan kebijakan pengembangan pegawai khususnya dan sumber daya manusia pada umumnya. 


\section{DAFTAR PUSTAKA}

A.A. Anwar Prabu Mangkunegara, 2004, Manajemen Sumber Daya Manusia Perusahaan, Cetakan Kelima, PT. Remaja Rosdakarya Offset, Bandung.

Alex Nitisemito, 2002, Manajemen Personalia, Cetakan ke-7, Ghalia Indonesia, Jakarta.

Basir Barthos, 2003, Manajer Sumber Daya Manusia, Cetakan Kelima, PT. Bumi Aksara, Jakarta.

Faustino Cardosa Gomes, 2005, Manajemen Sumber Daya Manusia, Edisi Pertama, Cetakan Ketiga, Andi Offset, Jakarta.

H. Abdurrahmat Fathoni, 2006, Manajemen Sumber Daya Manusia, Cetakan Pertama, PT. Rineka Cipta, Jakarta.

H. Kusnadi dkk, 2002, Pengantar Manajemen (Konseptual \& Perilaku), Universitas Brawijaya, Malang.

Henry Simamora, 2004, Manajemen Sumber Daya Manusia, Edisi Ketiga, Cetakan Pertama, STIE YKPN, Yogyakarta.

IG. Suroso, 2002, Disiplin Motivasi Dengan Kerja Karyawan, Edisi Pertama, PT. Intan, Klaten.

J. Supranto, 2004, Statistik (Teori dan Aplikasi) Jilid I, Edisi Kelima, Cetakan Kedelapan, Erlangga, Jakarta.

Jusuf Irianto, 2001, Tema-Tema Pokok Manajemen Sumber Daya
Manusia, Pengantar Kuliah di Perguruan Tinggi, Cetakan Pertama, Insan Cendekia, Jatim.

M. Manullang, 2004, Manajemen Personalia, Cetakan Sepuluh, Ghalia Indonesia, Jakarta.

Melayu S.P. Hasibuan, 2005, Manajemen Sumber Daya Manusia Dasar Dan Kunci Keberhasilan, Cetakan Pertama, CV. Haji Mas Agung, Jakarta.

Moh. Agus Tulus, 2004, Manajemen Sumber Daya Manusia, Buku Panduan Mahasiswa, PT. Gramedia Pustaka Utama, Jakarta.

Moh. As'ad, 2000, Psikologi Industri (Seri Ilmu Sumber Daya Manusia) Edisi Keempat, Liberty, Yogyakarta.

Muchdarsyah Sinungan, 2001, Produktivitas Apa Dan Bagaimana, Bumi Aksara, Jakarta.

Sedarmayanti, 2001, Sumber Daya Manusian Dan Produktivitas Kerja, Cetakan Kedua, Mandar Maju, Bandung.

Soekidjo Notoatmodjo, 2009, Pengembangan Sumber Daya Manusia, Edisi Revisi, Cetakan Kelima, PT. Rineka Cipta, Jakarta.

Sondang P.Siagian, 2005, Manajemen Sumber Daya Manusia,Cetakan Ke-5,Bumi Aksara, Jakarta.

Surya Dharma, 2005, Manajemen Kinerja (Filsafat Teori dan 
79 | Research Journal of Accounting and Business Management (RJABM); P-ISSN: 2580-3115; E-ISSN: 2580-3131

Penerapannya), Cetakan Pertama, Pustaka Pelajar, Yogyakarta.
T. Hani Handoko, 2005, Manajemen Personalia dan Sumber Daya Manusia, BPFE, Yogyakarta. 